\title{
Strategi Pengembangan Usaha Lebah Madu Kelompok Tani Mau Sigaro Hutan Kemasyarakatan Desa Gamsungi Kabupaten Halmahera Barat
}

\author{
Nurhikmah $^{1 *}$, Aqshan Shadikin Nurdin ${ }^{1}$, Laswi Irmayanti ${ }^{1}$, Meylinda Y Hanafi ${ }^{1}$ \\ ${ }^{1}$ Program Studi Kehutanan, Fakultas Pertanian, Universitas Khairun, Ternate \\ *E-mail: nurh8884@gmail.com
}

\begin{abstract}
The purpose of this study was to determine the activity of Mau Sigaro farmer group in Gamsungi village and identified internal and external factors that became the strengths, weakness, opportunities, and threats of the honey bee cultivation business, in order to find a good strategy to develop it using SWOT matrix. The result of SWOT analysis showed the strength point was consisted of professional human resorces, received capital assistance, produced a pure honey, and short marketing channel. The weakness of this farmer group was limited opportunity for all the member to join some workshop related to honey bee cultivation, needed more capital assistance to pay the maintenance expense, the price of the product was cheap, using manual technic, and none market promotion. The opportunities identified as the support from the government to the farmer group and it had gained consumer trust towards the product. The threats were found as weather exchange, it had not used technology to gain information, and it still did not have a permanent marketing partner to distribute the product. Alternative stategy can be used to develope the honey bee business based on SWOT result is Mau Sigaro farmer group needs to gain more relation with the government and marketing partner, increase the number of production and the quality of the product, send the member to join honey bee cultivation workshop, using the newest technology in honey bee cultivation and mass communication to spread the product information, and using an attractive packaging to gain more consumers.
\end{abstract}

Key words: developing strategy, farmer group, honey bee cultivation, SWOT

DOl:http:dx.doi.org/10.24259/jhm.v12i1.9921

\section{PENDAHULUAN}

Hutan kemasyarakatan adalah hutan negara yang pemanfaatan utamanya ditujukan untuk memberdayakan masyarakat (PermenKLHK, 2016). Pemberdayaan masyarakat tersebut dilihat sebagai upaya meningkatkan kemampuan dan kemandirian masyarakat untuk mendapatkan manfaat sumberdaya hutan secara optimal dan adil melalui pengembangan kapasitas dan pemberian akses. HKm merupakan satu dari tiga skema pengelolaan hutan kolaboratif yang dikembangkan oleh kementerian kehutanan bersama masyarakat (Sanjaya, dkk 2017). Salah satu Kelompok Tani Hutan (KTH) di Kabupaten Halmahera Barat yang memperoleh izin usaha pemanfaatan HKm adalah KTH Mau Sigaro Desa Gamsungi yang ditandai dengan terbitnya Keputusan Menteri Lingkungan Hidup dan Kehutanan Republik Indonesia dengan nomor SK.1490/MENLHK-PSKL/PKPS/PSL.0/4/2018 tanggal 05 April 2018 dengan areal kelola seluas 45 hektar pada kawasan Hutan Produksi Terbatas (HPT) untuk 34 kepala keluarga. Kesempatan mengakses hutan negara yang diberikan pemerintah melalui Kementerian Lingkungan Hidup dan Kehutanan dalam bentuk Izin Usaha Pemanfaatan Hutan Kemasyarakatan (IUPHKm) merupakan berkah bagi masyarakat Desa Gamsungi, terkhusus bagi KTH Mau Sigaro yang tinggal di sekitar hutan dan menggantungkan hidupnya dari potensi sumberdaya hutan yang ada. 
IUPHKm yang dikelola oleh KTH Mau Sigaro memiliki beberapa pengelolaan dan pemanfaatan Hasil Hutan Kayu (HHK) dan Hasil Hutan Bukan Kayu (HHBK). Potensi hutan seperti kayu, rotan, pala, dan madu merupakan hasil hutan yang berpotensi dikembangkan di areal HKm tersebut guna meningkatkan taraf ekonomi anggota kelompok khususnya dan masyarakat Desa Gamsungi umumnya. Hasil studi pendahuluan menunjukkan bahwa salah satu potensi HHBK yang masih berjalan hingga saat ini di KTH Mau Sigaro adalah usaha lebah madu. Lebah madu merupakan hasil hutan yang potensial dikembangkan dalam pembudidayaannya (Setiawan dkk, 2016). Sumber pakan yang berasal dari tumbuhan yang menghasilkan bunga mudah diperoleh. Hal ini didukung oleh penelitian yang dilakukan oleh (Mulyono dkk, 2015) yang mengungkap bahwa terdapat 37 jenis tanaman pakan lebah pada lokasi penelitiannya di PUSBAHNAS Parungpanjang Bogor.

Pengembangan usaha lebah madu yang dilakukan oleh KTH Mau Sigaro mulai dilakukan sejak tahun 2018 saat setelah terbitnya SK dari Menteri Lingkungan Hidup dan Kehutanan. Namun, saat ini aktivitas masyarakat dalam usaha ternak lebah madu tersebut mengalami penurunan. KTH Mau Sigaro yang berada di Desa Gamsungi dibina oleh Kesatuan Pengelolaan Hutan Lindung (KPHL) III Sasadu Bidadari, salah satu KPH yang berada di Kabupaten Halmahera Barat, Kecamatan Jailolo dengan luasan \pm 165.001 ha. Jumlah petani yang melakukan budidaya lebah madu sebanyak 34 kepala keluarga. Mereka membudidayakan lebah madu jenis Apis mellifera. Jenis ini tidak asing lagi di kehidupan masyarakat Indonesia dan banyak dibudidayakan oleh petani karena produksi madunya yang cukup tinggi jika dibandingkan dengan jenis lebah madu yang lain (Yunita dkk, 2019).

Budidaya jenis Apis mellifera dikembangakan secara intensif oleh para petani peternak lebah madu. Ada yang menjadikannya sebagai sumber pendapatan pokok maupun sebagai usaha sampingan. Terkhusus untuk KTH Mau Sigaro, petani menjadikan sebagai usaha sampingan atau sekadar menambah pendapatan petani. Menurut Setiawan (2016), salah satu faktor penyebab belum berkembangnya budidaya lebah madu karena kelompok tani tidak memiliki pengetahuan tentang pemeliharaan dan perawatan ternak yang tepat. Kajian lain dilakukan oleh Yunita (2019) yang mengungkap bahwa kurangnya keikutsertaan anggota kelompok karena anggota kelompok memiliki pekerjaan utama sebagai petani dan kegiatan budidaya lebah madu hanya dijadikan sebagai pekerjaan sampingan mereka.

Berkaitan dengan masalah tersebut, penelitian ini dilakukan untuk mendapatkan informasi mengenai kegiatan yang dilakukan oleh kelompok tani Mau Sigaro dalam usaha budidaya lebah madu dan faktorfaktor internal dan eksternal yang yang memengaruhi usaha budidaya lebah madu sehingga dapat ditentukan strategi pengembangannya kedepan yang diharapkan dapat menyuplai kebutuhan madu konsumen di tingkat desa, kecamatan, kabupaten, hingga ke lintas provinsi (nasional). 


\section{光}

\section{METODE PENELITIAN}

\subsection{Waktu dan Tempat penelitian}

Penelitian ini dilaksanakan pada kawasan hutan kemasyarakatan (HKm) Desa Gamsungi Kabupaten Halmahera Barat Provinsi Maluku Utara yang berada dalam kawasan Hutan Produksi Terbatas (HPT). Penelitian ini membutuhkan waktu selama 2 bulan, yaitu bulan September hingga November 2019

\subsection{Metode Pengumpulan Data}

Pengumpulan data dilakukan melalui data primer dan data sekunder. Data primer dilakukan melalui observasi dan wawancara. Observasi bertujuan untuk mengetahui kondisi awal dari objek penelitian, sedangkan wawancara dilakukan secara mendalam (indepth interview) kepada petani yang tergabung dalam KTH Mau Sigaro yang jumlahnya 30\% dari jumlah total anggota KTH. Populasi atau anggota KTH berjumlah 34 orang sehingga diambil 11 orang sebagai sampel penelitian untuk memenuhi $30 \%$ tersebut. Sampel terdiri dari ketua, sekretaris, bendahara, dan anggota. Sementara itu, pengumpulan data sekunder dilakukan melalui studi dokumen dan data-data dari instansi terkait.

\subsection{Analisis Data}

Analisis yang digunakan dalam penelitian ini adalah analisis deskriptif menggunakan teknik analisis SWOT. Formulasi alternatif strategi dilakukan dengan menggunakan analisis SWOT yaitu menganalisis peluang, ancaman, kekuatan, dan kelemahan. Kekuatan dan kelemahan diidentifikasi sebagai faktor internal, sedangkan peluang dan ancaman diindentifikasi sebagai faktor eksternal.

\section{HASIL DAN PEMBAHASAN}

\subsection{Gambaran Umum Lokasi Penelitian}

Lokasi budidaya lebah madu KTH Mau Sigaro yang berada di Desa Gamsungi dibina oleh Kesatuan Pengelolaan Hutan Lindung (KPHL) III Sasadu Bidadari. Lokasi ini memiliki prospek yang cukup baik dalam menghasilkan madu karena lokasinya tidak jauh dari perkebunan yang ditanam oleh masyarakat. Lebah yang diternakkan oleh masyarakat dapat memperoleh sumber makanan atau pakan dari perkebunan tersebut.

\subsection{Data Responden}

Data responden merupakan gambaran secara umum tentang keadaan dan latar belakang responden. Data responden tersebut tersaji dalam tabel 1 berikut.

Tabel 1. Data Responden anggota KTH Mau Sigaro

\begin{tabular}{|c|l|l|l|}
\hline No. & Inisial Resonden & Jenis Kelamin & Jabatan \\
\hline 1. & YU & L & Ketua \\
\hline 2. & RS & L & Sekretaris \\
\hline 3. & ES & L & Bendahara \\
\hline 4. & GS & L & Anggota \\
\hline
\end{tabular}




\begin{tabular}{|c|l|l|l|}
\hline 5. & EM & L & Anggota \\
\hline 6. & FB & L & Anggota \\
\hline 7. & DS & L & Anggota \\
\hline 8. & YB & L & Anggota \\
\hline 9. & MP & L & Anggota \\
\hline 10. & YB & L & Anggota \\
\hline 11. & HT & L & Anggota \\
\hline
\end{tabular}

\subsection{Kegiatan Kelompok Tani Hutan (KTH) Mau Sigaro}

Kegiatan budidaya lebah madu oleh KTH Mau Sigaro dimulai dari pemeliharaan dan perawatan, pemanenan, pengemasan, hingga pemasaran. Rangkaian kegiatan tersebut mempunyai teknik sehingga membutuhkan keahlian tersendiri. Farida (2000) mengungkap bahwa selain lahan dan modal, usaha budidaya lebah madu memerlukan tenaga kerja, pengetahuan, keterampilan, dan manajemen yang baik.

\subsubsection{Teknik Pemeliharaan dan Perawatan}

Komponen penting dalam pemeliharaan lebah yaitu peralatan dan pakan lebah (beeforage). Dari segi peralatan, cara tradisional seperti menggunakan glodok telah diubah dalam bentuk stup atau kotak oleh KTH Mau Sigaro. Ukurannya dibuat berdasarkan prinsip detail rancang bangun, sedangkan untuk bahan dan gaya menyesuaikan, tergantung kreativitas dari KTH. Untuk penempatan stup, diletakkan di tempat yang teduh. Kondisi keamanan stup dari gangguan semut maupun pengganggu lainnya seperti ngengat juga harus diperhatikan. Serangga yang biasanya menyerang lebah madu yaitu ngengat, tungau, semut, tabuhan vespa, dan tawon endas (Disbun Jatim, 2012). Karena itu, petani harus rajin memeriksa, menjaga, dan membersihkan bagian-bagian stup sehingga semut atau serangga lainnya tidak masuk. Selain itu, peralatan-peralatan pembantu lainnya juga diperlukan seperti masker, pisau, sikat lebah, tempat air, ekstaktor, dan lain-lain. Dari segi pakan lebah (beeforage), termasuk semua jenis tanaman berbunga, yaitu tanaman hutan, tanaman pertanian, tanaman perkebunan, maupun tanaman liar lainnya yang mengandung unsur-unsur nektar (madu), tepung sari (pollen), ekstrafloral, dan propolis (Disbun Jatim, 2012). Di sekitar lokasi budidaya lebah KTH Mau Sigaro, ketersediaan pakan cukup bagus sehingga memudahkan lebah untuk mencarinya.

\subsubsection{Teknik Pemanenan}

Selain untuk tujuan pengembangan, pemeliharaan lebah madu juga dilakukan untuk tujuan produksi (panen). Pemanenan dilakukan jika kotak/stup sudah penuh. Madu dari kotak bisa dipanen bila sisiran yang berisi madu telah tertutup oleh lapisan lilin. Sisiran dibersihkan terlebih dahulu dari lebah yang masih menempel (dipisahkan), lalu lapisan penutup sisiran dikupas dengan pisau yang telah direndam dengan air hangat. Selanjutnya sisiran dimasukkan ke ekstraktor dan diputar secara perlahan agar anakan tidak 
ikut terjatuh. Setelah itu, madu hasil perasan disaring dengan menggunakan kain kasa dan dimasukkan ke dalam botol kemasan dan ditutup rapat. Untuk penyimpanan, dilakukan di tempat yang kering, bersih, dan tidak berbau.

\subsubsection{Teknik Pengemasan}

Teknik pengemasan yang dilakukan oleh KTH Mau Sigaro masih dilakukan dengan cara tradisional, yaitu menggunakan botol. Hal ini menjadi kelemahan bagi kelompok tani karena botol yang digunakan belum menunjukkan identitas kelompok tani dan kurang menarik. Selain itu, kelompok tani juga belum menggunakan sarung tangan, masker, maupun pakaian khusus yang berguna bagi kehiegenisan produk.

\subsubsection{Pemasaran}

Dari hasil penelitian diperoleh informasi bahwa hasil produksi budidaya lebah yang dilakukan oleh petani hanya dengan menunggu konsumen langsung datang membeli kepada para petani. Konsumen masih bersifat lokal. Harga yang diberikan juga cenderung murah jika dibandingkan dengan harga di pasaran, yaitu Rp60.000,- dengan ukuran $150 \mathrm{ml}$. Usaha promosi belum dilakukan oleh para petani karena keterbatasan biaya, tidak adanya jaringan, dan minimnya waktu yang dimiliki oleh petani. Usaha ini hanya berjalan melalui mulut kemulut.

3.4 Identifikasi Faktor-faktor Internal dan Eksternal Pengembangan Usaha Budidaya Lebah Madu di Desa Gamsungi

Strategi pengembangan usaha lebah madu dapat dirumuskan dengan terlebih dahulu mengidentifikasi faktor-faktor internal dan eksternal yang memengaruhi pengembangan budidaya lebah madu. Berdasarkan penelitian (Yunita dkk, 2019) menyebutkan bahwa faktor internal budidaya lebah madu di Kelurahan Kalampangan meliputi: tenaga kerja, produksi, dan pemasaran. Sedangkan faktor eksternal meliputi: pemerintah, pesaing, teknologi, dan lingkungan. Hal tersebut tidak jauh berbeda dengan penelitian yang dilakukan oleh Setiawan, dkk (2016) yang mengungkap bahwa SDM, produksi, pemasaran, dan harga sebagai faktor internal, sedangkan pemerintah, lingkungan, dan konsumen sebagai faktor eksternal dari pengembangan budidaya lebah madu di Desa Ramba Jaya. Berdasarkan penelitian di lapangan serta penelitian-penelitian sebelumnya, faktor internal dan eksternal dalam budidaya lebah madu di Desa Gamsungi kemudian disajikan pada tabel 2 dan tabel 3 berikut.

Tabel 2. Kekuatan dan Kelemahan dalam Pengembangan Budidaya Lebah Madu di Desa Gamsungi

\begin{tabular}{|l|l|l|l|}
\hline No. & Faktor Strategi Internal & Kekuatan/Strengths (S) & Kelemahan/Weaknesses (W) \\
\hline 1. & $\begin{array}{l}\text { Sumber daya Manusia } \\
\text { (SDM) }\end{array}$ & $\begin{array}{l}\text { Anggota kelompok tani telah } \\
\text { mengikuti pelatihan }\end{array}$ & $\begin{array}{l}\text { Terbatasnya anggota KTH yang } \\
\text { mengikuti pelatihan }\end{array}$ \\
\hline 2. & Modal & Adanya bantuan modal & Sulitnya modal tambahan untuk \\
\hline
\end{tabular}




\begin{tabular}{|l|l|l|l|}
\hline & & $\begin{array}{l}\text { berupa alat ekonomi } \\
\text { produktif dan bibit lebah } \\
\text { madu jenis Apis mellifera } \\
\text { dari Balai Perhutanan Sosial } \\
\text { dan Kemitraan Lingkungan } \\
\text { (BPSKL) Wilayah Maluku- } \\
\text { Papua }\end{array}$ & \\
\hline 3. & Produk & $\begin{array}{l}\text { Produk madu benar-benar } \\
\text { produk murni }\end{array}$ & Produk terbatas \\
\hline 4. & Harga & Ada penentuan harga & Harga madu cenderung murah \\
\hline 5. & Alat Produksi & Menggunakan alat produksi & $\begin{array}{l}\text { Alat produksi yang digunakan masih } \\
\text { manual }\end{array}$ \\
\hline 6. & Pemasaran & Saluran distribusi pendek & $\begin{array}{l}\text { Belum dilakukan promosi } \\
\text { Kemasan belum menarik }\end{array}$ \\
\hline
\end{tabular}

Sumber: Analisis Data Primer, 2019

Tabel 3. Peluang dan Ancaman dalam Pengembangan Budidaya Lebah Madu di Desa Gamsungi

\begin{tabular}{|c|c|c|c|}
\hline No. & Faktor Strategi Eksternal & Peluang/Opportunities (0) & Ancaman/Threats ( $\mathrm{T}$ ) \\
\hline 1. & Pemerintah & Adanya dukungan pemerintah & \\
\hline 2. & Konsumen & $\begin{array}{ll}\text { Kepercayaan } & \text { konsumen } \\
\text { terhadap produk } & \end{array}$ & \\
\hline 3. & Lingkungan & & Perubahan cuaca \\
\hline 4. & Teknologi & & $\begin{array}{l}\text { Belum memanfaatkan } \\
\text { teknologi untuk } \\
\text { memperoleh informasi }\end{array}$ \\
\hline 5. & Kemitraan & & $\begin{array}{l}\text { Belum tersedia mitra tetap } \\
\text { dalam pemasaran hasil }\end{array}$ \\
\hline
\end{tabular}

Sumber: Analisis Data Primer, 2019

\subsubsection{Kekuatan (Strenghts)}

a. Keikutsertaan Anggota Kelompkk Tani (sumberdaya manusia) dalam Pelatihan

Jumlah SDM yang terlibat dalam KTH Mau Sigaro cukup banyak, yaitu 34 orang. Hal ini menjadi faktor utama dalam setiap pembangunan organisasi atau KTH. Anggota KTH Mau Sigaro telah mengikuti pelatihan meskipun tidak semuanya diikutkan. Bentuk pelatihan yang pernah diikuti yaitu Sekolah Lapang Pengolahan Produk dan Pemasaran di Kabupaten Halmahera Barat Provinsi Maluku Utara Tahun 2018 
yang bertempat di Jailolo pada tanggal 17-20 Oktober 2018. Sekolah Lapang ini dilakukan oleh Balai Perhutanan Sosial dan Kemitraan Lingkungan Wilayah Maluku-Papua dalam rangka menyiapkan dan meningkatkan sumber daya manusia, dalam hal ini petani hutan yang tergabung dalam Kelompok Tani Hutan (KTH) dan kelompok usaha perhutanan sosial (KUPS). KTH Mau Sigaro melibatkan 3 KUPS, yaitu KUPS Mau Sigaro, KUPS Mau Dadalara, dan KUPS Kasih.

\section{b. Adanya bantuan modal}

Anggota KTH Mau Sigaro mendapatkan modal dari Balai Perhutanan Sosial dan Kemitraan Lingkungan (BPSKL) Wilayah Maluku-Papua berupa bibit lebah madu berjenis Apis mellifera dan alat ekonomi produktif. Apis mellifera tergolong lebah yang jinak, mudah dipelihara, dan mempunyai produksi madu yang cukup tinggi (Sumoprastowo dan Suprapto, 1993). Hal ini menjadi alasan mengapa jenis tersebut banyak dibudidayakan. Selain mendapat modal dari BPSKL, anggota KTH juga mendapatkan modal untuk biaya pemeliharaan hingga panen yang diperoleh secara swadaya.

\section{c. Produk madu murni}

Salah satu produk yang dihasilkan dari lebah itu sendiri adalah madu. Madu merupakan cairan kental yang dihasilkan oleh lebah dari nektar bunga. Madu hasil dari lebah yang ditampung dengan metode pengambilan modern berupa cairan jernih dan bebas dari benda asing (Molan, 1999). Madu yang diproduksi oleh KTH Mau Sigaro merupakan madu yang benar-benar murni, teksturnya kental dan lengket, tidak berair, menempel jika menyentuh apapun dan tidak menetes seperti air.

\section{d. Saluran pemasaran pendek}

Saluran pemasaran yang berjalan di KTH Mau Sigaro menggunakan saluran nol tingkat (zero -level). Bentuk saluran ini merupakan bentuk saluran yang paling pendek dan sederhana sebab tidak menggunakan perantara (Kotler dan Keller, 2007). Konsumen yang membeli produk madu untuk dikonsumsi sendiri.

\subsubsection{Kelemahan (Weaknesses)}

a. Terbatasnya anggota KTH yang mengikuti pelatihan

Anggota KTH Mau Sigaro berjumlah 34 orang sehingga jika dilakukan pelatihan seperti sekolah lapang tidak dapat diikutkan secara keseluruhan. Hal ini dapat berdampak pada transfer ilmu yang kurang maksimal. Selain itu, beberapa dari anggota lebih fokus pada pekerjaan utama sebagai petani. Kegiatan budidaya lebah madu masih berupa pekerjaan sampingan.

\section{b. Sulitnya modal tambahan untuk biaya pemeliharaan hingga panen}

Modal merupakan unsur penting dalam suatu usaha, tidak terkecuali usaha budidaya lebah madu. Tanpa modal yang cukup, aktivitas operasional tidak dapat dilangsungkan (Subagio dkk, 2017). Dari segi modal, KTH Mau Sigaro memperolehnya melalui swadaya masyarakat saat kelompok tani dibangun untuk 
biaya pemeliharaan hingga panen. Modal tambahan sangat diperlukan untuk mengembangkan usaha ternak lebah madu. Hal tersebut bisa didapatkan jika kelompok tani mempunyai mitra atau bantuan dari pemerintah secara berkala saat kelompok tani membutuhkan. Setelah modal tercukupi, kelompok tani diharapkan dapat mandiri mengembangkan usaha budidaya lebah madunya.

\section{c. Harga cenderung murah}

Harga didefinisikan jumlah uang yang harus diserahkan konsumen untuk membeli suatu produk atau jasa (Peter dan Olson, 2000). Sedangkan Swastha \& Irawan (2005) menyatakan bahwa harga adalah jumlah uang (ditambah beberapa produk kalau mungkin) yang dibutuhkan untuk mendapatkan sejumlah kombinasi dari produk dan pelayanannya. Harga merupakan salah satu elemen yang berkaitan dengan pendapatan selain biaya dan penerimaan. Pendapatan KTH Mau Sigaro dalam melakukan usaha budidaya lebah madu akan baik jika harga dari madu sesuai. Namun, hal ini belum sesuai yang diinginkan. KTH Mau Sigaro menjual produk madu mereka dengan harga yang cenderung masih murah jika dikaitkan dengan kualitasnya, yaitu Rp60.000,- dengan ukuran $150 \mathrm{ml}$. Di pasaran, harga madu bisa mencapai Rp100.000,- dengan ukuran 200 ml dan Rp250.000,- dengan ukuran $500 \mathrm{ml}$.

d. Alat produksi yang digunakan masih manual

Alat produksi merupakan input non-manusia dan fisik yang digunakan untuk produksi nilai ekonomi, seperti mesin dan alat. Untuk KTH Mau Sigaro, dalam melakukan kegiatan pemeliharaan dan perawatan, pemanenan, pengemasan, dan pemasaran masih dilakukan dengan cara tradisional dan manual yang artinya memakai campur tangan manusia sehingga hasil yang diperoleh kurang maksimal.

e. Belum dilakukan promosi

Promosi adalah bentuk komunikasi pemasaran, artinya aktivitas pemasaran yang berusaha menyebarkan informasi, memengaruhi/membujuk dan atau mengingatkan pasar sasaran atau perusahaan dan produknya agar bersedia menerima, membeli, dan loyal pada produk yang ditawarkan perusahaan yang bersangkutan (Tjiptono, 2002). Usaha lebah madu pada KTH Mau Sigaro belum dilakukan promosi, baik melalui media elektronik maupun media cetak seperti brosur dan sebagainya. Pemasaran masih dari mulut ke mulut atau sekitar wilayah desa.

f. Kemasan belum menarik

Kemasan produk madu KTH Mau Sigaro masih sederhana karena masih menggunakan kemasan botol plastik biasa dengan ukuran $330 \mathrm{ml}, 600 \mathrm{ml}$, hingga $1.500 \mathrm{ml}$. Dalam kemasan, belum terdapat merk dagang, label halal, dan persyaratan lain yang biasanya dimiliki oleh kemasan produk madu lainnya. Hal ini mengindikasikan bahwa kemasan belum menarik dan belum layak untuk dipasarkan dalam skala yang lebih luas. 


\section{In}

\subsubsection{Peluang (Opportunities)}

a. Adanya dukungan pemerintah

Usaha lebah madu di KTH Mau Sigaro mendapatkan dukungan dari pemerintah, dalam hal ini Balai Perhutanan Sosial dan Kemitraan Lingkungan (BPSKL) Wilayah Maluku-Papua. Dukungan yang diberikan berupa bantuan bibit lebah madu Apis mellifera sebanyak 6 setup dan alat ekonomi produktif. Selain itu, pemerintah juga melakukan program yang terkait dengan budidaya lebah madu, yaitu Sekolah Lapang Pengolahan Produk dan Pemasaran di Kabupaten Halmahera Barat Provinsi Maluku Utara Tahun pada tahun 2018.

\section{b. Kepercayaan konsumen terhadap produk}

Produk merupakan segala sesuatu yang dapat ditawarkan ke pasar untuk mendapatkan perhatian, dibeli, digunakan atau dikonsumsi yang dapat memuaskan keinginan atau kebutuhan, mencakup ragam, kualitas, desain, fitur, merk, dan kemasan (Kotler et al, 2011). Untuk mendapatkan kepercayaan dari konsumen, hal yang dapat dilakukan berupa memberikan kesan pertama yang baik terhadap konsumen, melakukan komunikasi yang baik, memberikan harga yang masuk akal, serta memberikan kualitas yang baik. Dalam usaha lebah madu KTH Mau Sigaro, konsumen yang langsung datang ke produsen telah percaya terhadap kualitas madu karena langsung melihat sendiri. Selain itu, konsumen juga cukup puas dengan kualitas madu yang dibeli. Namun, jumlah konsumen belum terlalu banyak. Disamping karena sistem pemasaran yang jangkauannya belum luas, jumlah produksi madu yang tergolong masih sedikit juga menjadi faktor penghambatnya.

\subsubsection{Ancaman (Threats)}

\section{a. Perubahan Cuaca}

Perubahan cuaca dapat memengaruhi produksi dan kualitas madu. Hal ini sesuai dengan penelitian yang dilakukan oleh Yunita, dkk (2019) yang menyebutkan bahwa cuaca menjadi hal yang penting dalam menunjang usaha budidaya lebah madu yang disebabkan oleh udara panas yang membuat lebah madu menjadi agresif dibandingkan biasanya sehingga peternak mengalami kesusahan dalam tahap pembuatan lebah ratu, pemecahan, dan penggabungan koloni lebah madu. Hal ini justru berbanding terbalik jika musim hujan, lebah akan lebih sering berdiam di dalam kotak dan tidak bisa mencari makan. Hal tersebut membuat produksi madu menjadi berkurang. Karena itu, peternak lebah dituntut untuk beradaptasi dengan perubahan cuaca. Selain cuaca, masa paceklik juga bisa memengaruhi produksi lebah madu. Saat masa paceklik, tidak tersedia pakan di sekitar lokasi pemeliharaan sehingga koloni lebah dalam keadaan kekurangan pakan.

\section{b. Belum memanfaatkan teknologi untuk memperoleh informasi}

Perkembangan teknologi informasi berdampak pada segala kehidupan manusia, termasuk usaha budidaya lebah madu. Anggota KTH dapat mencari berbagai informasi yang beredar di dunia maya yang 
berkaitan dengan budidaya lebah madu. Namun, beberapa KTH termasuk KTH Mau Sigaro belum memanfaatkan perkembangan teknologi untuk memperoleh informasi terkait lebah madu. Hal ini disebabkan tidak ada atau belum bagusnya akses jaringan pada wilayah $\mathrm{HKm}$ tersebut. Dalam hal pemasaran produk, dilakukan dengan sistem pemasaran word of mouth (WOM), yaitu berdasarkan komunikasi lisan dan informasi dari orang ke orang atau mulut ke mulut.

c. Belum tersedia mitra tetap dalam pemasaran hasil

Dalam pengembangan hutan kemasyarakatan $(\mathrm{HKm})$ dalam hal ini adalah KTH Mau Sigaro sebagai bagian dari HKm Desa Gamsungi, kerja sama antara kelompok tani dan mitra (dalam hal ini adalah pelaku pasar) menjadi hal yang krusial. Namun, di KTH Mau Sigaro mitra tetap dalam pemasaran hasil belum ada. Kelompok tani cenderung langsung menjual hasil madunya kepada konsumen yang langsung datang ke lokasi HKm.

\subsubsection{Alternatif Strategi Pengembangan Budidaya Lebah Madu di Desa Gamsungi}

Setelah dilakukan identifikasi terhadap faktor-faktor internal dan eksternal yang menjadi kekuatan, kelemahan, peluang, dan ancaman dalam usaha budidaya lebah madu Desa Gamsungi, selanjutnya dirumuskan alternatif strategi yang bisa diterapkan dalam mengembangkan usaha budidaya lebah madu KTH Mau Sigaro Desa Gamsungi kedepannya.

Tabel 4. Strategi dengan Matriks SWOT Pengembangan Usaha Lebah Madu Kelompok Tani Mau Sigaro Desa Gamsungi

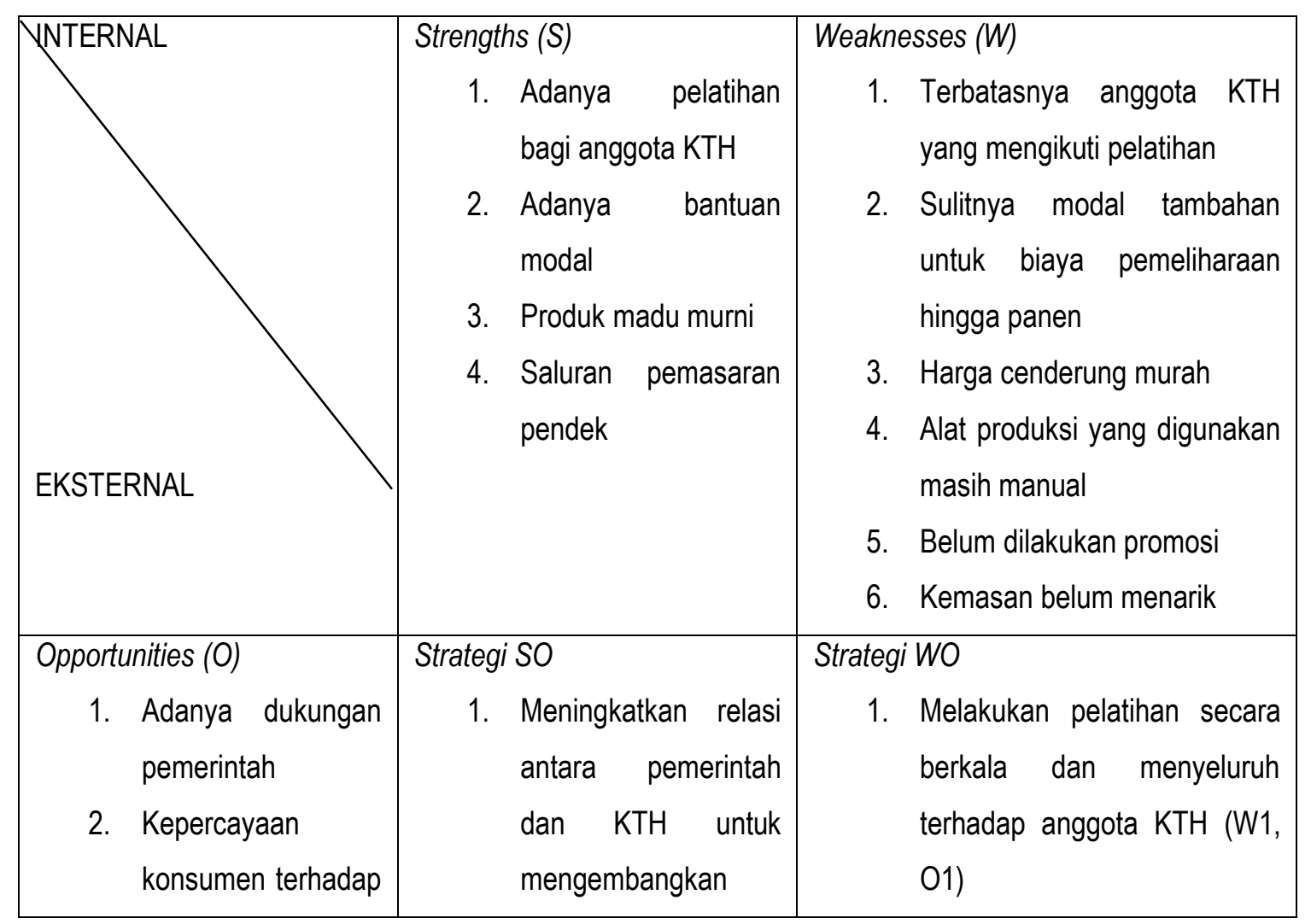




\begin{tabular}{|c|c|c|c|}
\hline produk & 2. & 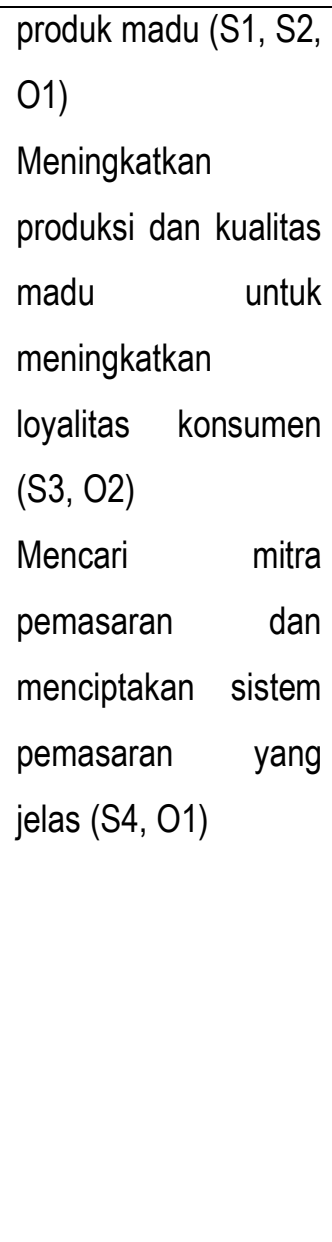 & 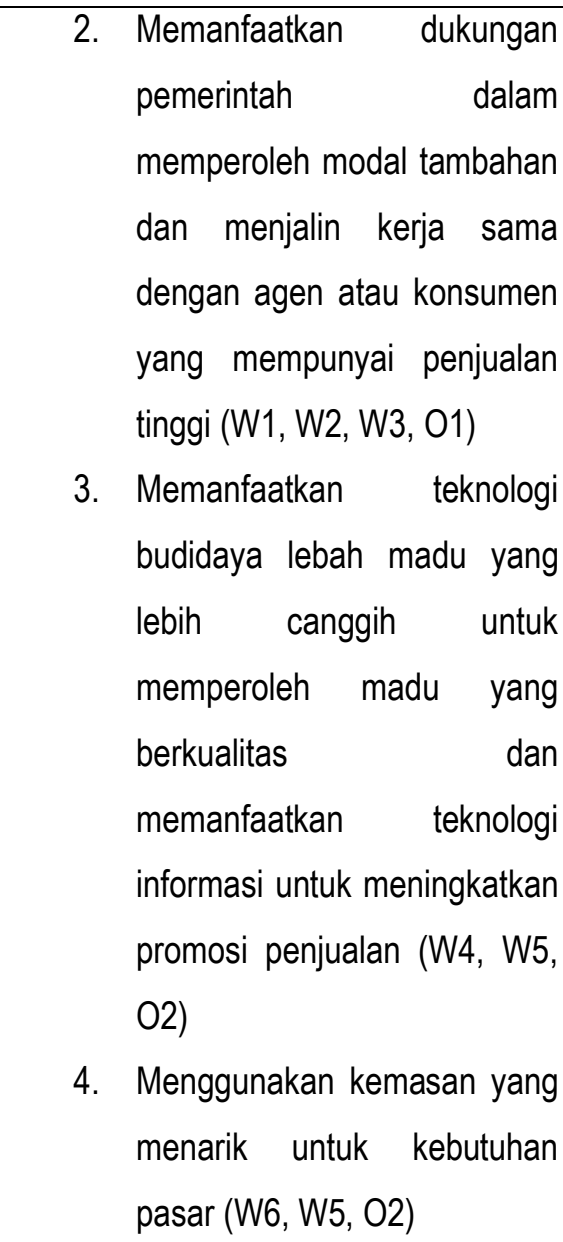 \\
\hline $\begin{array}{ll}\text { Threats } & (T) \\
\text { 1. } & \text { Perubahan cuaca } \\
\text { 2. } & \text { Belum } \\
& \text { memanfaatkan } \\
& \text { teknologi untuk } \\
& \text { memperoleh } \\
& \text { informasi } \\
\text { 3. Belum tersedia } \\
\text { mitra tetap dalam } \\
\text { pemasaran hasil }\end{array}$ & $\begin{array}{c}\text { Strategi } \\
1 .\end{array}$ & 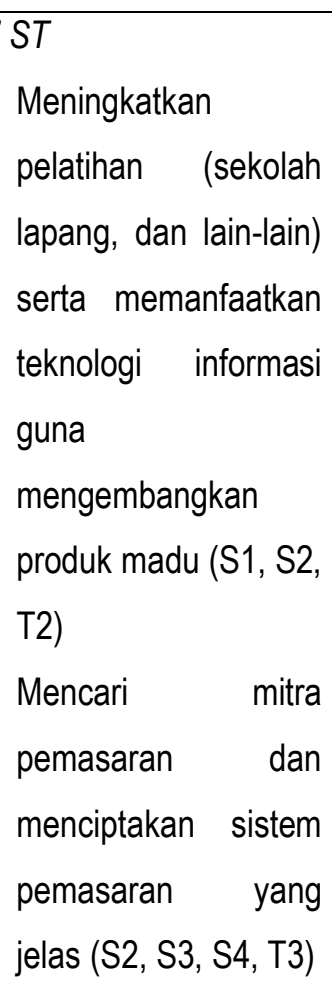 & $\begin{array}{l}\text { Strategi WT } \\
\text { 1. Memanfaatkan teknologi yang } \\
\text { lebih canggih untuk } \\
\text { memperoleh produksi madu } \\
\text { yang lebih baik (W4, W3, T2) } \\
\text { 2. Melakukan promosi, baik } \\
\text { secara langsung maupun } \\
\text { melalui media (W5, W2, W6, } \\
\text { T2, T3) } \\
\text { Melakukan pelatihan secara } \\
\text { berkala guna mengetahui } \\
\text { cara adaptasi terhadap } \\
\text { perubahan cuaca (W1, T1) }\end{array}$ \\
\hline
\end{tabular}

Sumber: Analisis Data Primer, 2019 
Berdasarkan analisis matriks SWOT, maka diperoleh alternatif strategi yang dapat diterapkan dalam mengembangkan usaha ternak madu di Desa Gamsungi. Adapun alternatif strategi tersebut adalah sebagai berikut:

Strategi S-O (Strength-Opportunity):

a. Meningkatkan relasi antara pemerintah dan $\mathrm{KTH}$ untuk mengembangkan produk madu;

b. Meningkatkan produksi dan kualitas madu untuk meningkatkan loyalitas konsumen;

c. Mencari mitra pemasaran dan menciptakan sistem pemasaran yang jelas.

Strategi W-O (Weaknesses-Opportunity):

a. Melakukan pelatihan secara berkala dan menyeluruh terhadap anggota KTH;

b. Memanfaatkan dukungan pemerintah dalam memperoleh modal tambahan dan menjalin kerja sama dengan agen atau konsumen yang mempunyai penjualan tinggi;

c. Memanfaatkan teknologi budidaya lebah madu yang lebih tinggi untuk memperoleh madu yang berkualitas dan memanfaatkan teknologi informasi untuk meningkatkan promosi penjualan;

d. Menggunakan kemasan yang menarik untuk kebutuhan pasar.

Strategi S-T (Strength-Threat):

a. Meningkatkan pelatihan (sekolah lapang, dan lain-lain) serta memanfaatkan teknologi informasi guna mengembangkan produk madu;

b. Mencari mitra pemasaran dan menciptakan sistem pemasaran yang jelas.

Strategi W-T (Weakness-Threat):

a. Memanfaatkan teknologi yang lebih canggih untuk memperoleh produksi madu yang lebih baik;

b. Melakukan promosi, baik secara langsung maupun melalui media;

c. Melakukan pelatihan secara berkala guna mengetahui cara adaptasi terhadap perubahan cuaca.

\section{KESIMPULAN}

Faktor-faktor internal (kekuatan dan kelemahan) dan eksternal (peluang dan ancaman) pengembangan budidaya lebah madu di Desa Gamsungi yaitu kekuatan terdiri atas: adanya pelatihan bagi anggota kelompok tani, adanya bantuan modal, produk madu murni, dan saluran pemasaran pendek. Kelemahan terdiri atas: terbatasnya anggota KTH yang mengikuti pelatihan, sulitnya modal tambahan untuk biaya pemeliharaan, harga cenderung murah, alat produksi yang digunakan masih manual dan belum dilakukan promosi. Sedangkan peluang terdiri atas: adanya dukungan pemerintah dan kepercayaan konsumen terhadap produk. Sementara untuk ancaman terdiri atas: perubahan cuaca, belum memanfaatkan teknologi untuk memperoleh informasi dan belum tersedia mitra tetap dalam pemasaran hasil.

Usaha budidaya lebah madu di Desa Gamsungi masih perlu dilakukan pengembangan lebih lanjut. Alternatif strategi yang dapat diterapkan yaitu mulai dari peningkatan relasi antara pemerintah, kelompok tani, maupun mitra, peningkatan produksi dan kualitas madu, pelatihan budidaya lebah madu secara 
berkala, pemanfaatan teknologi budidaya dan teknologi informasi untuk pemasaran produk, serta penggunaan kemasan yang menarik sehingga dapat meningkatkan daya tarik konsumen.

\section{DAFTAR PUSTAKA}

Dinas Perkebunan Provinsi Jawa Timur. 2012. Budidaya Lebah Apis Mellifera di Sekitar Kawasan Perkebunan. Diakses pada tanggal 11 Maret 2020.

Farida, I. 2000. Evaluasi Perkembangan Usaha Lebah Madu Apis mellifera (Studi Kasus pada Perusahaan Industri Kecil Madu Odeng Cibubur Jakarta). Skripsi Jurusan Sosial Ekonomi Industri Peternakan Fakultas Peternakan IPB. Diakses pada tanggal 12 Maret 2020.

Kementerian Kehutanan. 2016. Peraturan Menteri Lingkungan Hidup dan Kehutanan Nomor:P.83/Menlhk/Setjen/Kum.I/10/2016 tentang Perhutanan Sosial.

Kotler dan Keller. 2007. Manajemen Pemasaran Edisi 12, Jilid 1. Jakarta: PT.Indeks.

Kotler., Philip., and Amstrong. 2011. 10"thedition “Marketing an Introduction" Indonesia: Perason

Molan P C. 1999. The role of honey in the management of wounds. Journal of Wound Care. 8: 423-426.

Mulyono., Susdiyanti, T., dan Supriono, B. 2015. Kajian Ketersediaan Pakan lebah Madu Lokal. Jurnal Nusa Sylva Fakultas Kehutanan Universitas Nusa Bangsa.

Paul, J.L., and J. C. Olson. 2000. Consumer Behavior: Perilaku Konsumen dan Strategi Pemasaran. Terjemahan. Jakarta: Erlangga.

Sanjaya, R., Wulandari, C., dan Herwanti, S. 2017. Evaluasi Pengelolaan Hutan Kemasyarakatan (HKm) pada Gabungan Kelompok Tani Rukun Lestari Sejahtera di Desa Sindang Pagar Kecamatan Sumberjaya Kabupaten Lampung Barat. Jurnal Sylva Lestari Vol.5 No.2, April 2017: 30-42.

Setiawan, A., Sulaiman R., dan Arlita T. 2016. Strategi Pengembangan Usaha Lebah Madu Kelompok Tani Setia Jaya di Desa Rambah Jaya Kecamatan Bangun Purba Kabupaten Rokan Hulu. Jom Faperta Vol. 3 No.1 Februari 2016.

Subagio, K.M.P., Dzulkirom, M., dan Hidayat, R.R. 2017. Analisis Pengelolaan Modal Kerja dalam Upaya Meningkatkan Likuiditas dan Profitabilitas (Studi Kasus PT. Gudang Garam Tbk Periode 20142016). Jurnal Administrasi Bisnis (JAB) Vol. 50 No. 1 Oktober 2017.

Sumoprastowo, R.M dan Suprapto, R.A. 1993. Beternak Lebah Madu Modern. Jakarta: PT. Bharata Karya Aksara.

Swastha, B. dan Irawan. 2005. Manajemen Pemasaran Modern. Yogyakarta: Liberty.

Tjiptono, F. 2002. Strategi Pemasaran. Yogyakarta: Penerbit Andi.

Yunita, Pordamantra., dan Berkat, A.P. 2019. Strategi Pengembangan Budidaya Lebah Madudi Kelurahan Kalampangan Kecamatan Sabangau Kota Palangka Raya. Jurnal Socio Ekonomis Agricultural Vol. 14 No. 1, Februari 2019: 62-71 